\title{
Designing and Evaluating the Solar Roof Top Plant Interconnectivity System for the Residential Buildings
}

\author{
${ }^{1}$ Chandragiri Radhacharan, ${ }^{\square}{ }^{2}$ Sonnaila Vishnu Vardhan \\ ${ }_{1,2}$ Department of Electrical and Electronics Engineering, JNTUH College of Engineering, Nachupally, Jagtial, \\ Telangana \\ cradhacharan55@gmail.com,vishnuvardhan.sonnaila@gmail.com
}

Received: 18th July 2020, Accepted: 27th July 2020, Published: 31st August 2020

\begin{abstract}
To accomplish the installation of capacity target Solar Roof Top Plants set by Ministry of New Renewable Energy (MNRE) is an absolute essential requirement of installing the Solar Roof Top Plants in India. A salient and efficient system, pre-estimation and anticipation is indispensable. A 91.8 KW system of Solar Roof Top Plant within the 14 Residential Building's is achieved by the using the cloud based Helioscope software. It is designed and located with the help of this software. Increasing the reliability of system by establishing the Interconnectivity. For the better and efficient energy flow a Hybrid Inverter and a Charge Controller is used. Battery Management System (BMS) is used for smart and efficient storage system. Lithium Ferro Phosphate (LFP) batteries are used to reduce the thermal run-away in batteries. Usage of Bi-directional meter for recording the energy flow bidirectionally. Effectuating the Sub-Metering system for realizing the energy consumption and production of the Residential Solar Roof Top Plant. The performance ratio, annual production and potential energy yield per installed capacity $(\mathrm{kWh} / \mathrm{kWp})$ are calculated by using the Helioscope software. Cost Analysis of the system is done to estimated the investment, power production and consumption. Calculated the savings amount, Internal Rate of Return and observed the payback period in 11.965 (i.e. approximately 12 years).
\end{abstract}

\section{Keywords}

Solar RTP, HELIOSCOPE Software, Battery System, Hybrid Inverter, Interconnectivity System, Net-Metering.

\section{Introduction}

In India, there is a consecutive incremental change in population and diminishing of the fossil fuels which is effecting our electricity production and management system. To meet the forecasted demand of electricity we need to go for Renewable and Environmental friendly sources so as to maintain the sustainability. Among renewable energy sources Solar and Wind plants are preferable. Presently, India is aiming to complete target production of $175 \mathrm{GW}$ electricity through Renewable Expansion program till 2022 and Solar roof top plants (RTP) of capacity target installation of 40GW till 2022[1] is given by Ministry of New and Renewable Energy(MNRE) and for the Residential Solar Roof Top Plants central government is providing 20\% of Central Finance Assistance(CFA) an amount of 11,814Crores is sanctioned[2]. And our Telangana state government is providing about $40 \%$ of subsidy for $1-3 \mathrm{KWp}$ plant and for above capacity an amount of CFA of $20 \%$ is provided by the Telangana State Renewable Energy Development Corporation Ltd..,(TSREDCO) on Solar Roof Top Plant(RTP) on ON-GRID systems which is very beneficial for installing Solar RTPs[3].Planning or pre-estimation is very important for installing a solar PV system or plant. In here HELIOSCOPE is the software which is used for modeling the solar PV system[4]. Helioscope software is simple and efficient cloud based software. FOLSOM Labs(USA) has developed this Helioscope software. Here a 91.8 KW Solar RTP system is located and designed using the Helioscope software.

- Designing an affordable and manageable conceptual design of Solar Roof Top Plant(RTP).

- Developing a Battery and Inverter system setup, so as both government and resident can be benefited.

- Implementing an Inter-Connective system for the Solar RTP and connecting the system to grid.

- Modeling the Solar RTP for residential building .

- Estimating the cost of system, calculating the power production \& consumption of system, obtaining the payback period and calculating the expected profit.

- Listing the reports obtained in HELIOSCOPE software after designing the RTP on residential building.

Design of Solar Roof Top Plant

Selected a pertinent location where solar RTP system can be installed. In here a colony is selected and installation of Solar RTP is done based on the dimensions of the buildings by using the HELIOSCOPE. Power generation through solar panels is an environment friendly but its production of electricity mainly depends on environmental conditions. So forecasting of weather is very much important aspect in Solar RTP. Weather data set conditions are taken from Typical Metrological Year (TMY), RAMAGUNDAM, ISHRAE. Condition sets includes all environmental effects, weather forecasted data, shading and soiling that can alter the performance of the Solar RTP. Typical Metrological Year (TMY) is an arranged data, which comprises of climatic and weather forecasted 
data of some years in hourly basis for a given particular location. The Indian Society of Heating, Refrigerating and Air Conditioning Engineers (ISHRAE), was established in 1981 at New Delhi by a group of eminent HVAC\&R professionals [5].

Solar RTP mainly consists of Solar panels, Charge controller, Inverter, Battery setup, Net Metering, Sub-Metering system.

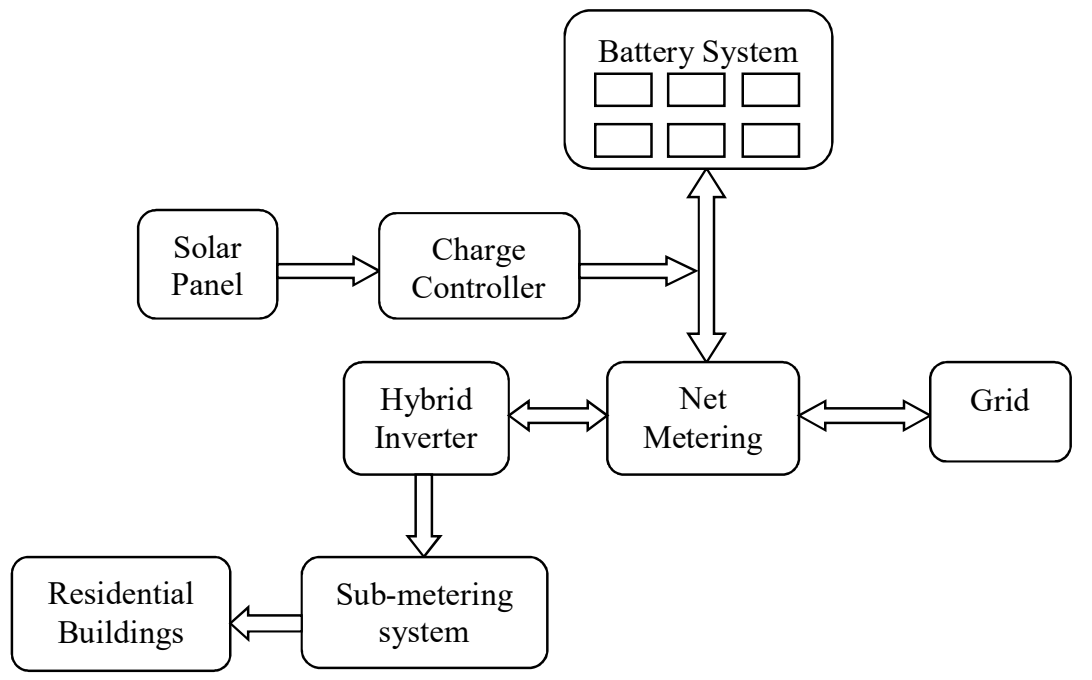

Fig. 1: Block Digram of Solar RTP

A. Solar Panel

Selection of Solar panels is main part in generation of electricity through solar energy. As per the comparisons done by the Energy sage marketplace, SUNPOWER is providing $22.8 \%$ efficiency and second LG company with $21.7 \%$ efficiency [6]. In this SUNPOWER X-series module of 21.5\% efficiency SUNPOWER-SPR-X21-345 is utilized.

1) Characteristics of SPR-X21-345 module[7]:

Open circuit voltage $=68.2 \mathrm{~V}$

Short circuit current $=6.39 \mathrm{~A}$

Power temperature coefficient $=-0.29 \% / \mathrm{C}^{\circ}$

Solar Array sizing $=38 * 7$

seven modules in series (i.e. string) and 38 strings in parallel. Each module contains 96 solar cells of Monocrystalline.

B. Charge Controller

Charge controller is used for better functioning and high reliability. Charge controllers are used to protect from battery cut-off protection, low voltage protection, over discharging from battery system protection and reverse current protection.

C. Battery and an Inverter Setup

Battery and Inverter setup is used so the residential owners can also be benefited along with the government.

1) Inverter: Normally Inverters are two types Traditional Inverter and Hybrid Inverter. A hybrid inverter is the integrated system of both off-grid inverter (traditional inverter) and on-grid inverter with inbuilt charge controller. A traditional inverter converts Direct current (DC) from solar panels into Alternating Current(AC), where as the hybrid inverter not only converts the DC of solar panel to AC but also does the other multi-functioning .

Hybrid Inverter allows the battery system to be charged simultaneously while sending the alternating current(ac) supply to loads and grid. They are supportive for the generator connection and provides over current protection, over voltage protection and short circuit protection, Anti-islanding protection, PV surge protection, leakage current protection and PV string reverse polarity protection. They also has zero export functioning.

In here SUNSYNX-HYBRID-8KW-Inverter of 230volts single phase inverter with 3-stage MPPT charging for optimal battery system functioning. It provides over load protection, short circuit protection and temperature protection. It's an user friendly inverter with digital and a programmable system. It supports Wi-Fi monitoring of the system.

2) Battery System: Battery system is the backup system which is used at the time of outages of electricity. Among the batteries lithium-ion and lead acid batteries are mostly in use. lithium-Ion batteries are preferred over the lead acid batteries due to its high DOD(Depth of Discharge) and compact ability. They are lighter in weight, required less maintenance and provides longer life when compared with the lead acid batteries. In lithium-ion batteries chemical composition of lithium-ions are used. According to International Market Analysis Research \& 
Consulting Group(IMARC) Automotive energy supply corporation, LG chem and Panasonic are the top companies which are providing reliable and efficient Lithium-Ion batteries[8]. Performance of the batteries are determined based on the factors of DOD, Battery capacity, Power rating and Round Trip Efficiency(RTE). As listed by IMARC, Panasonic providing smart and reliable energy storage system with Battery Management Unit and Battery protection unit.

A Battery Management System or Unit (BMS) consists battery modules and cells either connected in series or parallel. It provides system a better stabilization of energy flow. BMS is very crucial thing in Lithium-ion batteries installation. BMS protects the battery cells and it regulates the voltage level. Lithium-ion batteries are little sensitive due to this they need BMS. BMS is used as a link between batteries, inverter and charge controller to regulate the energy flow. They are designed to store the energy during the Off-Peak and discharge the energy while peak demand conditions.

As in India the temperature is very high it is very essential to use a batteries which are high tolerance towards the temperature. Lithium Ferro phosphate (LFP or LiFePo4) batteries have high temperature tolerance, less thermal run-away and best suitable to the environmental conditions of India.

D. Net-Metering

It's the connection provided by the state power distribution company limited (DISCOM) which enables the connection between RTP to the Grid. The processes of getting Net metering connection from the DISCOM and its detailed guidelines for implementation[9] and flowchart of Net Metering are provided by Northern Power Distribution Company Of Telangana Limited(A Govt. of Telangana undertaking)[10]. A Bidirectional meter is efficient to be used in Net metering.

1) Bidirectional Meter: A Bidirectional meter is the meter which records the energy bidirectional, which helps the consumers a lot. Bidirectional meters also come in single phase and three phase based on the requirements of the system the meters are choosen. Single phase whole current Energy Meter EM101+[11] is the one of the Bidirectional meter. It has anti-tampering features and they come with compact ability feature which is manufactured by the L\&T electrical and Automation. And it also secured by the multi level password for the data reading and programming.

E. Sub-Metering System

Due to the complexity structural buildings made in India there is a need to use the Sub-Metering system. Submeters are used as to differentiate the consumption and production of electricity from the each and every residential in the system.

F. Interconnectivity(Inter-Connective) System

Establishing the inter-connective system between the residential buildings of Solar RTP, So as to increase the reliability of the system. By this the system functioning(operational) cost and maintenance cost is reduced and the system becomes economical. And the operational efficiency of the System is increased by the interconnectivity of the Solar RTP.

\section{Modeling of Solar Roof Top Plant}

The energy produced by the Solar RTP is used to store the energy in the BMS, supply the electricity to the residential buildings by using the hybrid inverter and the surplus electricity is sent to the grid by using the net metering system.

\section{A. Functioning of Solar RTP as Follows}

- Solar RTP is producing electricity, Battery Management System(BMS) is not fully charged than batteries are charged through the MPPT or PWM and the residential buildings are supplied from the Grid.

- Solar RTP are producing less amount of energy than the required amount of running the residential buildings and batteries are almost fully charged than the surfeit(surplus) energy from batteries(BMS) is sent to residential buildings and the differential energy is taken from the grid.

- If the load at residential is less or zero than the power is fed to the grid which earns profit for residents.

- At the time of outages the solar and battery power is supplied for residential buildings, if outages occur at night than the only the BMS is used to supply electricity to residential buildings primarily for the essential loads only.

- If solar is unavailable and BMS is discharged than the grid power is used for batteries and residential buildings. 
Cost Estimation and Energy Consumption, Production Details

A. Cost Estimation of the Plant

Table 1: Cost Estimation

\begin{tabular}{|l|l|l|l|l|l|l|}
\hline Equipment Name & $\begin{array}{l}\text { Amount } \\
\text { (Unit) }\end{array}$ & $\begin{array}{l}\text { Unit Price } \\
\text { in Rupees } \\
\text { (Approx) }\end{array}$ & $\begin{array}{l}\text { Tax } \\
\%\end{array}$ & $\begin{array}{l}\text { Discount } \\
\% \\
\text { (Approx) }\end{array}$ & $\begin{array}{l}\text { Net Price } \\
\text { in Rupees } \\
\text { (Approx) }\end{array}$ & $\begin{array}{l}\text { Total Price } \\
\text { in Rupees } \\
\text { (Approx) }\end{array}$ \\
\hline SunPower-SPR-X21-345 & 266 & 10000.00 & $20 \%$ & $7 \%$ & 2660000.00 & 2968560.00 \\
\hline 8KW Hybrid Inverter & 10 & 226530.00 & $18 \%$ & $5 \%$ & 2265300.00 & 2539401.30 \\
\hline Lithium Ferro Phosphate Batteries & 20 & 265000.00 & $18 \%$ & $8 \%$ & 5300000.00 & 5753680.00 \\
\hline
\end{tabular}

Net Sum $\quad=\quad$ Rs.1,02,25,300.00

Tax Sum $\quad=\quad$ Rs. $18,93,754.00$

Gross Sum $\quad=\quad$ Rs. $1,21,19,054.00$

Discount $\quad=\quad$ Rs. $8,57,412.70$

Total Sum $\quad=\quad$ Rs. $1,12,61,641.30$

Miscellaneous charges $=$ Rs.3,23,800.00 (approx)

Overall Total Sum = Rs.1,15,85,441.30 (approx)

Other miscellaneous charges includes purchasing and installation charges of Net Metering, Sub Metering system.etc.

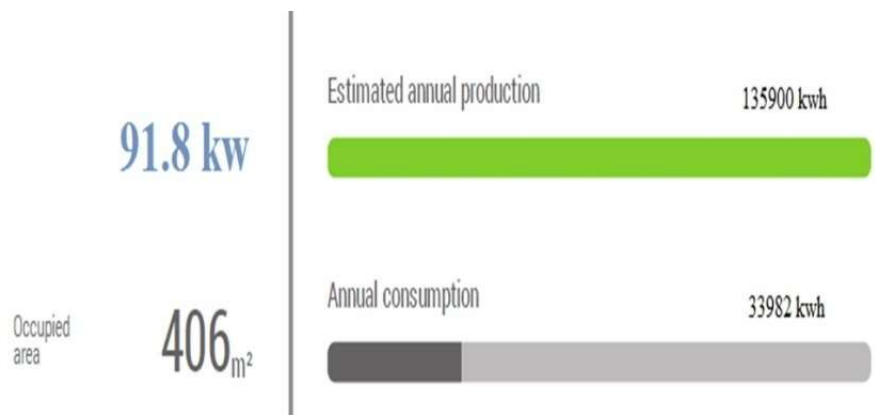

Fig. 2: Estimated Annual Production and Consumption

The above "Fig. 2", shows the area occupied and the estimated annual production and consumption.

$B$. Let us consider each residential house is consuming power as follows

Table 2: Energy Consumption Details

\begin{tabular}{|l|l|l|l|l|l|}
\hline $\begin{array}{l}\text { S. } \\
\text { No }\end{array}$ & Appliances & Numbers & $\begin{array}{l}\text { Wattage of } \\
\text { each(W) }\end{array}$ & $\begin{array}{l}\text { No. of working } \\
\text { hours (h) }\end{array}$ & $\begin{array}{l}\text { Total wattage } \\
\text { consumption (Wh) }\end{array}$ \\
\hline 1 & Tube Lights & 3 & 40 & 5 & 600 \\
\hline 2 & Led Bulbs & 3 & 15 & 4 & 180 \\
\hline 3 & Fans & 4 & 60 & 7 & 1680 \\
\hline 4 & Television & 1 & 80 & 7 & 560 \\
\hline 5 & Refrigerator & 1 & 180 & 16 & 2880 \\
\hline 6 & Iron (Electrical) & 1 & 750 & 1 & 750 \\
\hline & & & & Total & 6650 Watt hours \\
\hline
\end{tabular}

1) Calculation of Power consumption and production \& Payback Period:

Per an each residential buildings wattage consumption $=6650 \mathrm{Wh}$

For 14 residential buildings wattage consumption $=93100 \mathrm{Wh}$

Power consumption per day $=93.1 \mathrm{kWh}$ (i.e. 93.1 units)

Power consumption per month(30 days) $=2793$ units

Energy Charges for 2793 units(Current tariff above 800 units is 9.5)[12] = Rs.26,534(Approx)

Power consumption per Year(365 days) $=33982$ units

Energy Charges for 33982 units(Current tariff above 800 units is 9.5) = Rs.3,22,829(Approx)

Estimated Annual production(365 days) $=135900$ units

Energy Charges for 135900 units(Current tariff above 800 units is 9.5) $=$ Rs.12,91,050(Approx)

Savings per year $=$ Production-Consumption

$$
\begin{aligned}
& =12,91,050-3,22,829 \\
& =\text { Rs.9,68,221(Approx) }
\end{aligned}
$$

PAYBACK period $=11.965$ years (i.e. Approximately 12 years).

Life span of solar panel is approximately 25 years so remaining 13 years is profitable.

Expected Profit $=$ Saving amount $\times$ No. of Years

$$
\begin{aligned}
& =\text { Rs.9,68,221×13 } \\
& =\text { Rs.1,25,86,873(Approx.) }
\end{aligned}
$$


Internal Rate of Return (IRR) [13] is calculated by $N V P=\sum_{n=0}^{N} \frac{C F_{n}}{(1+I R R)^{n}}$

Where as:

$\mathrm{NVP}=$ Net Present Value $=0$

IRR=Internal Rate of Return

$\mathrm{CF}_{0}=$ Initial investment in the system

$\mathrm{CF}_{1}, \mathrm{CF}_{2} \ldots \ldots \mathrm{CF}_{\mathrm{n}}=$ Cash flows in the system

$\mathrm{n}=$ representing each year

$\mathrm{N}=$ representing holding year

IRR for this system is 7\% based on the current Tariff it may be increased based on the Electricity Tariff rates.

\section{Result and Discussion}

A. System Metrics and System Field Segments

The System Metrics includes details of system performance, annual production, other system monitoring and affecting factors. System metrics and detailed list of System field segments with power production is shown in below "Fig. 3(a), 3(b)".

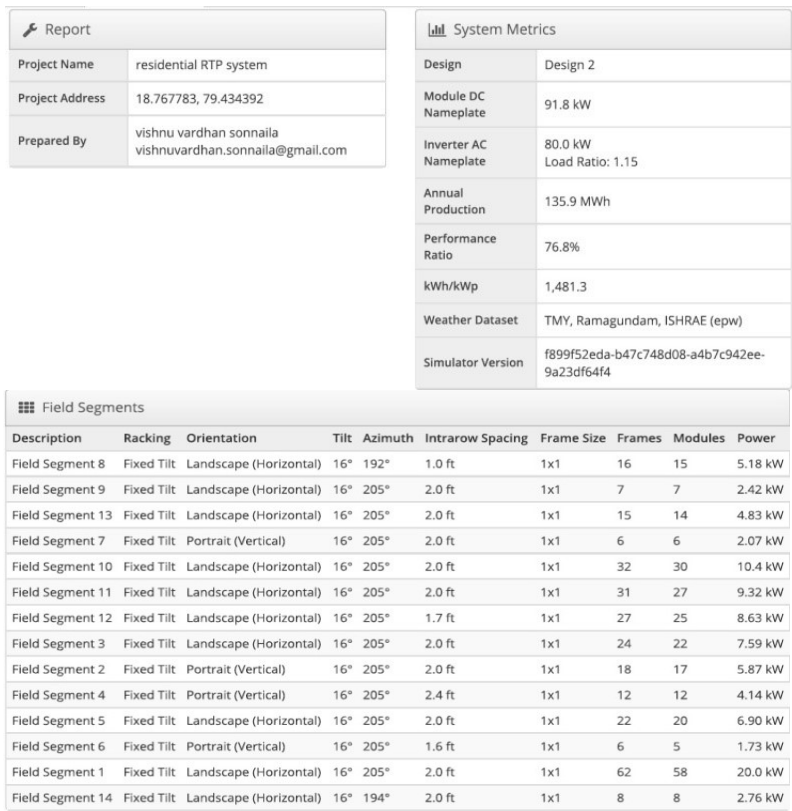

(a)

(b)

Fig. 3: (a) System Metrics; (b) List of Field Segments

B. Project Location Before Installation and After Installation

The below "Fig. 4 (a)", shows the geographical location of the system represents where we want to install the Solar Roof Top Plant and "Fig. 4 (b)", shows the geographical location after the installation in the Helioscope.

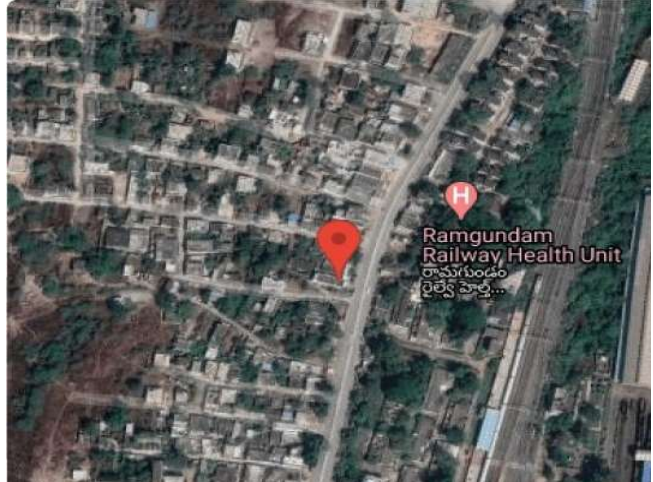

(a)

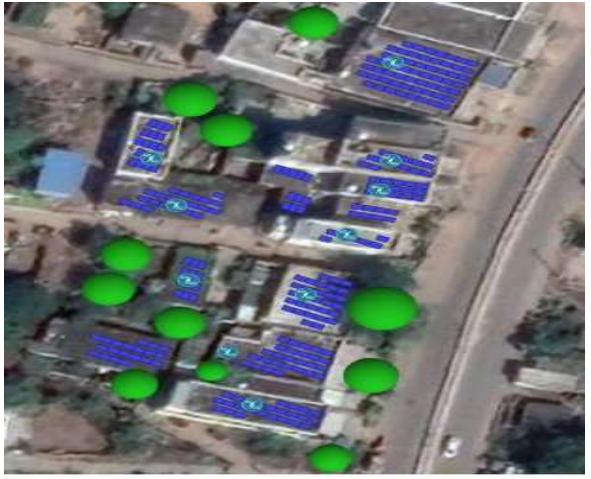

(b)

Fig. 4: (a) Geographical Location Before Installation; (b) Geographical Location After Installation 
C. Losses of the System

The System losses represents the sources of losses due to which system performance is affected. Soiling, Temperature, Reflection, Mismatch, Wiring, Irradiance, AC system and Inverters losses are the Sources of losses in the system. An total losses of $25.7 \%$ is observed in the system by using Helioscope.

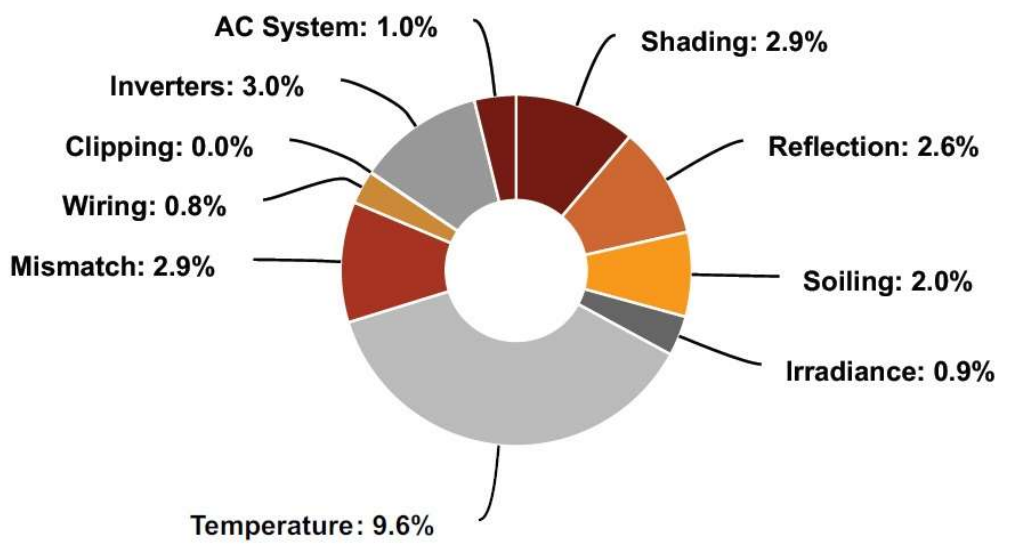

D. Bar Graph of Monthly Production

Fig. 5: Losses in System

Here "Fig. 6", shows the detailed difference in production of system. Solar produces more energy in summer while compared to other seasons this also can observed by this Bar graph.

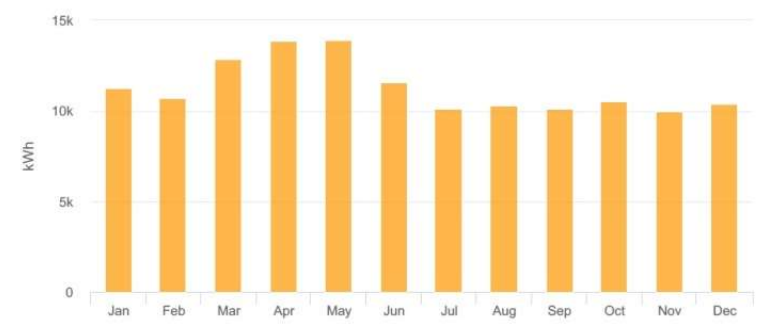

Fig. 6: Bar Graph Representing Annual Production

\section{Conclusion}

This analysis is carried out for a Residential Colony in the RAMAGUNDAM City. Solar roof top plant with interconnectivity system is designed by using the HELIOSCOPE software. Analyzed the system losses by using Pi chart, the annual production of system by using the bar graph. Block diagram is represented for easy understanding of system. Usage of bi-directional meter in the net-metering, simple sub-metering system and the smart Battery Management Unit for the better reliability and performance of the system. An annual estimated production of $135900 \mathrm{kWh}$ power and annual consumption of $33982 \mathrm{kWh}$ is observed in system. Cost analysis of the system is carried out and an investment of Rs. 1,15,85,441.30 (approx), saving amount of Rs.9,68,221(approx) is calculated. The Payback period of investment is estimated in the span of 11.965 i.e. approximately 12 years. Life span of solar panel is around 25 years so, expected calculated profit for remaining 13 years is Rs.1,25,86,873(Approx). Internal rate of return is calculated as 7\%. A detailed list of residential houses and their power production is calculated as $91.8 \mathrm{~kW}$. Potential energy yield per installed capacity is observed to be $1481.3 \mathrm{kWh} / \mathrm{kWp}$. Considering the system losses (includes Soiling, Temperature, Reflection, Mismatch, Wiring, Irradiance, AC system and Inverters losses) of $25.7 \%$, Panel efficiency of $21.5 \%$ an annual production of 135.9MWh and performance ratio of $76.8 \%$ is observed by using the Helioscope software.

\section{References}

[1] Goel and Malti, "Solar Rooftop in India: Policies, Challenges and Outlook," Elsevier, Green Energy \& Environment, 1.10.1016/j.gee.2016.08.003, Vol. 1, Issue. 2, pp. 129-137, July 2016.

[2] Target and the Sanctioned CFA Launch of Phase-2, Roof Top Solar Plants, document No.318/331/2017GCRT Division, MNRE, March 2019, Retrieved from https://solarrooftop.gov.in/notification/Notification08032019-181024.pdf

[3] Implementation of Solar Rooftop Plants subsidy payments under GCRT Division, Phase-2, Telangana State Renewable Energy Development Corporation Ltd.., Issued. 20 th January 2020, Retrieved from https://tsredco.telangana.gov.in/Solar_Rooftop_plants_subsidy payments.aspx 
[4] Li, Hong Xian, Zhang, Yitao, Edwards, David, Hosseini and M. Reza, "Improving the energy production of roof-top solar PV systems through roof design,” Building Simulation.13, 10.1007/s12273-019-0585-6, pp. 475-487, 2019.

[5] ISHRAE-The Indian Society of Heating, Refrigerating and Air Conditioning Engineers, ISO 9001:2015. https://ishrae.in/Home/about ishrae accessed on $4^{\text {th }}$ July 2020

[6] Vikram Aggarwal, Buyer's guide, ENERGYSAGE, 12th July 2016. Retrieved from https://news.energysage.com/what-are-the-most-efficient-solar-panels-on-the-market/ accessed on $4^{\text {th }}$ July 2020

[7] Characteristics of SPR-X21-345 module, SUNPOWER Corporation, Datasheet, Document \# 504828 Rev F /LTR_US, December 2016, Retrieved from https://us.sunpower.com/sites/default/files/media-library/datasheets/ds-x21-series-335-345-residential-solar-panels.pdf

[8] Top 10 Lithium-Ion Battery Manufactures published, IMARC, $22^{\text {th }}$ July 2019 . Retrieved from https://www.imarcgroup.com/top-lithium-ion-battery-manufacturers accessed on $4^{\text {th }}$ July 2020

[9] Guidelines for implementation of Net Metering for Solar Roof top PV grid interactive system, TSNPDCL. http:/www.tsnpdcl.in/ShowProperty/NP CM REPO/Pages/Media/Announcements/Solar\%20Rooftop\%20 net $\% 20$ metering/Guidelines

[10] Solar Roof top PV system Net Metering Flow chart, TSNPDC, 2017. http://www.tsnpdcl.in/ShowProperty/NP CM REPO/Pages/Media/Announcements/Solar\%20Rooftop\%20 net $\% 20$ metering/Solar\%20Flow\%20chart $\% 202017$

[11] Single phase Whole Current Energy Meter EM101+, L\&T Electrical and Automation, L\&T MetersDatasheet. https://corpwebstorage.blob.core.windows.net/media/39358/single-phase-whole-current-energymeter-em101plus.pdf accessed on $4^{\text {th }}$ July 2020

[12] Retail Supply Tariff Order for FY 2018-19 - Salient features, Telangana State Electricity Regulatory Commission, Press Note: $27^{\text {th }} \quad$ March $\quad 2018, \quad$ Retrieved from http://www.tserc.gov.in/file_upload/uploads/Tariff $\% 20$ Orders/Tariff $\% 20$ Schedule/Tariff $\% 20$ Schedule $\% 20 \mathrm{f}$ or\%20FY2018-19.pdf

[13] Bethany McCamish, Internal Rate of Return, Investing Answer, Inc, updated August 2020, Retrieved from https://investinganswers.com/dictionary/i/internal-rate-return-irr 